\title{
CONTINUOUS TRAINING OF TEACHERS IN ROMANIAN PRE-UNIVERSITY EDUCATION DURING THE PANDEMIC. SUCCESS FACTORS
}

\author{
Roxana Constanța ENACHE ${ }^{1}$, Ana-Maria Aurelia PETRESCU ${ }^{2}$, Mihaela PREDOI ${ }^{3}$ \\ ${ }^{1}$ Teacher Training Department, Technical University of Civil Engineering, Bucharest, \\ 2 Teacher Training Department, Valahia University of Târgoviște, \\ ${ }^{3}$ Mihai Viteazul Secondary School, Târgoviște, \\ ROMANIA, \\ E-mail: ${ }^{1}$ rocatare@yahoo.com , ${ }^{2}$ anapetrescu2007@yahoo.com, \\ 3 mihaelacantea@yahoo.com
}

\begin{abstract}
This paper presents the issue of continuous teacher training in pre-university education in the context of online school, as dictated by the current pandemic. Through this study, we wanted to highlight the importance of training and refresher courses for teachers with a view to online teaching during the pandemic, as well as to identify the success factors of continuous training programs in the perception of Romanian teacher. This research is carried out on a sample of 70 teachers in Romanian pre-university education, from rural and urban areas, using the questionnaire as a research tool. As a result of this research, we concluded the following:

- Teachers do not feel very well prepared for online teaching;

- Teachers need IT skills and time management skills when teaching online;

- 53\% of the respondents have attended a training course to acquire online teaching skills, the rest managed to assimilate these skills with the help of other sources;

- More than half of the respondents consider the experience of trainers in continuous training courses very important;

- A disadvantage highlighted by most respondents is the amount of the participation fee.

This study has highlighted important issues concerning the preparation of teachers in pre-university education and the criteria they follow when choosing a course or continuous training programme. At the same time, the study led to the identification of some success factors associated with continuous training programmes, in relation to: training of trainers, teaching strategies - methods, means, forms of organisation used.
\end{abstract}

Keywords: continuous teacher training; pandemic context; pre-university education in Romania; success factors;

\section{INTRODUCTION}

Teacher training reflects on the teacher's career as well as on the beneficiaries of education. There is no one right field in which a teacher needs to improve, as they need information from a wide range of fields and need training on several levels. Each continuous training programme will empower teachers and give them more inspiration in the design of instructional activities. (https://gov.ro/fisiere/programe_fisiere/stratform.pdf) 
The profile of the competent teacher must include research and innovation skills required by educational reform and demanded by today's society. In this respect, we include the following skills: appropriate use of methods and techniques for researching educational phenomena, identifying the new in experimental situations, developing research objectives, ways to test a hypothesis, selecting and using working tools, team work, identifying solutions, using research results, etc. (Șerbănescu, Bocoș, Joja, 2020, p.30).

In other words, a teacher is open-minded, reflective, resilient, enthusiastic, showing perseverance, courage, originality, respect for others, open to new things, observant, critical, a team player and well-balanced throughout the teaching process.

In the modern conception of continuous training, the teacher is seen as a member of a defined organisational structure, such as a school, and a member of a community, and plays an important role in both environments. The teacher is expected to be reflective, open, empathetic, pragmatic and creative both within the training system and in their daily work. (Forest Divonne, 2019, p.27)

With the evolution of society and technology, changes are also occurring in the educational sciences, especially in the instructional process carried out by teachers. All these changes and problems that teachers encounter especially in the classroom and in the school organisational environment in general, are being recognised and lead to a 'problemsolving' approach. (Reghintovschi, 2021, p.31)

Self-improvement is the teachers' concern for their own development, based on their motivation, aspiration and subjective condition.

The whole change and evolution of the school is closely linked to the continuous training of teachers. The level of teachers' competence and the degree of their involvement in the teaching and learning process are significant factors that are certainly leading to educational reform. (Iucu, 2004, p.15)

\section{MODELS OF CONTINUOUS TRAINING FOR THE TEACHING CAREER}

In order to improve European education, there has been much controversy about the advantages and disadvantages of continuous teacher training. There have been many changes in European education over the last three decades. These changes are in the structure, duration and content of the training programme to meet the needs of society and the individual.

In all European countries, the aim is to provide teachers with both in-depth specialist knowledge and new professional skills. The whole educational process must be analysed in a relevant way so as to meet the different educational needs of pupils. (Călin, Pistritu, 2015, p.11)

Twenty years ago, PISA surveyed teachers to track their participation in continuous training programmes, resulting in an average of $40 \%$ of teachers participating. (http://publications.europa.eu/resource/cellar/d7834ad0-ddac-11e9-9c4e01aa75ed71a1.0011.01/DOC_1 )

In 2006, the ETUCE also showed in a survey that about half of the participants in continuous training programmes considered the conditions for continuous professional development unsatisfactory. This is mostly due to the lack of remuneration employees get from the organisation. In half of the countries surveyed merit awards were given to teachers. (https://eur-lex.europa.eu/legal-content/ro/TXT/?uri=CELEX:52017DC0248) 
This is a sensitive topic in 2021, as participation in teacher training courses and programmes is not adequately remunerated.

The ETUCE survey also tracked teachers' satisfaction with in-service training courses, with teachers dissatisfied with the quality, quantity and subjects offered. (Șerbănescu, Bocoș, Joja, 2020, p.12). In a complex society, which is in a state of continuous development based very much on technological progress, and which is concerned with the professionalisation of all fields of action, the teacher is seen as an essential element in the development of all the above-mentioned elements. This is why education systems have put teacher training first. For a long time now, teachers have not been seen simply as transmitters of information and knowledge, but as the people who encourage pupils to learn through discovery, to develop personally and to be creative and innovative.

(https://www.researchgate.net/publication/301823079_Formarea_profesionala_a_cadrelor didactice_-_repere_pentru_managementul_carierei)

Throughout their professional career, teachers must improve themselves, acquire interdisciplinary and professional skills in order to adapt to the new demands of today's society. Generations of pupils change from year to year, the determining factor being today's changing society and the environment in which pupils live. Teachers must therefore keep up with their pupils, update their information and skills in order to achieve educational performance.(https://concursurilecomper.ro/rip/2014/februarie2014/17-PanaitAlina

Politici_educationale.pdf)

Teaching staff in Romania can improve their skills through individual study, participation in various actions at the level of the educational institution such as conferences and methodological clubs, committees, enrolment in symposia, conferences, attending training courses outside the educational institution, obtaining teaching degrees, completing training modules offered by the Teacher Training Departments and pursuing university and post-graduate studies. (https://legeaz.net/legea-educatiei-nationale-1-2011/art-245)

\section{RESEARCH METHIODOLOGY}

The research was based primarily on the questionnaire survey method, applied to a sample of 70 pre-university teachers.

The questionnaire, administered with the help of Google Forms, was structured on 10 items, one of which was open-ended and the other 9 were closed, predetermined answers. The research instrument was designed in such a way as to help us identify the most frequent but also impactful success factors of continuous training programmes for teachers in Romanian pre-university education during the pandemic period.

The hypothesis underlying this study was the following: If the training program is organized by a well-known, experienced training provider, with trainers who have psychopedagogical training using attractive, participatory, modern teaching strategies, with an affordable participation fee, interesting, varied and necessary contents for teachers facing problematic situations in the fields of educational marketing, postmodern strategies, inclusive education, project management, then the success of the proposed courses is high and with a significant impact on the professional development of the participating teachers.

The research sample is made up of 70 respondents, teachers in Romanian preuniversity education who have undergone online continuous training programs during the pandemic, the majority of whom are female (93\%), most of them with more than 20 years 
of teaching experience, from urban and rural areas, from preschool, primary, secondary, high school and vocational education, with various specializations.

In order to identify the reasons for the choice of the continuous training programmes and to rank them, the respondents ranked as the most important ones in item 1: the accumulation of professional credits and the gaining of professional experience, even the sharing of good practices; the least important were deemed to be the acquisition of psychopedagogical and methodological knowledge and the training of professional skills.

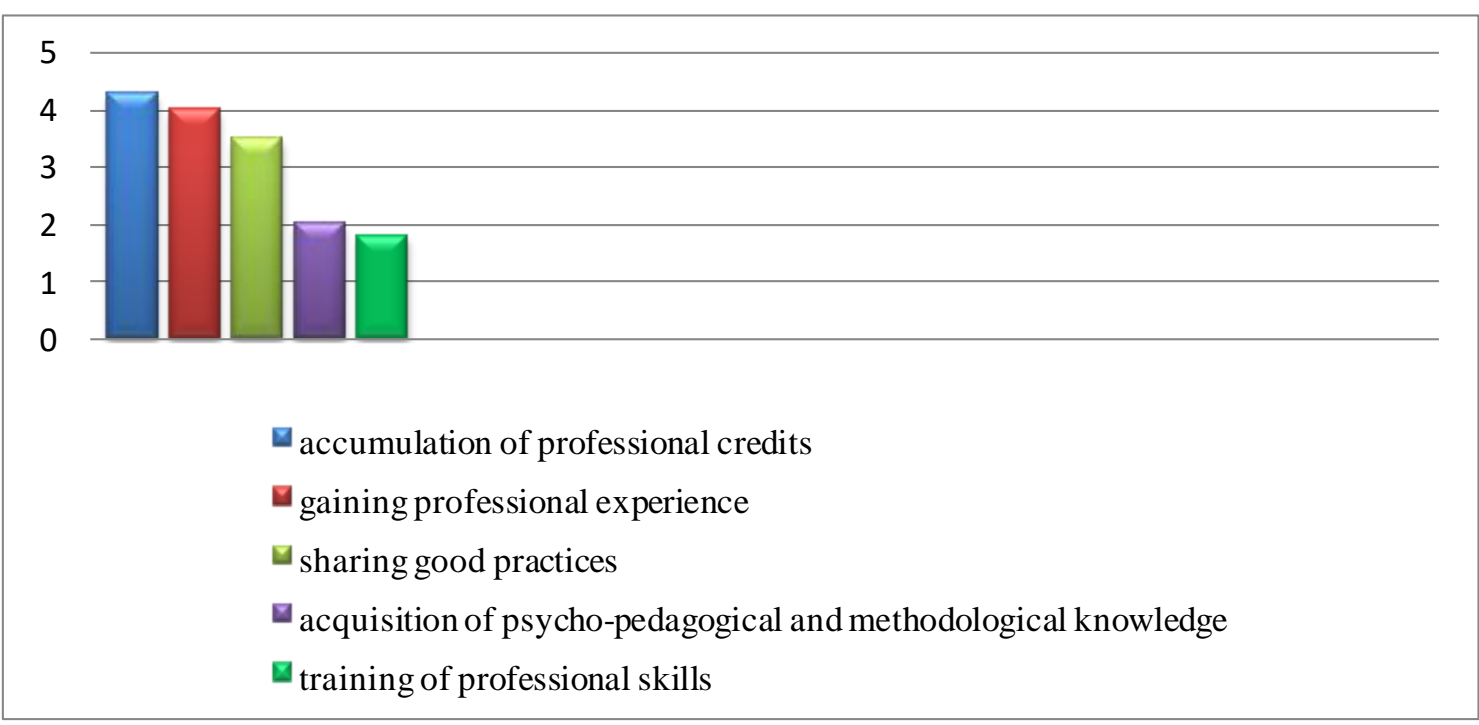

Figure no. 1 Teachers' perceptions of the reasons for choosing a continuous training programme

In the next item respondents were asked to refer to their last training programme and identify what they felt it had contributed to their professional development. Among the most frequent answers we list:

- $\quad$ Training professional skills, developing self-esteem and rediscovering more interactive methods; I learned marketing techniques, it was one of the most interesting and "different" courses I have done!

- $\quad$ The ideas and information provided by the trainers helped me a lot, but I was also inspired by the opinions of my classmates, understanding the constructivist approach in Romanian education; I understood Educational Marketing better.

- $\quad I$ understood the mistakes I was making in conducting a SWOT analysis, I learned new things about educational platforms, I exchanged best practices with my classmates and listened very carefully to the trainers who conducted interesting interactive activities, I learned how important it is to promote the school in the local, county, national community, improving the constructivist style in my professional development.

- I Inderstood that it is important to become a flexible teacher, to relate more to the affective dimension of the relationship with students, I learned to design the lesson focusing on the behavioural involvement of students, on learning through discovery, on valuing the creativity and originality of students, to assess not only knowledge but also other values: behaviours, competencies formed, skills, strategies used.

- We received concrete examples of best practice, an adaptation to the new, a restructuring of knowledge, a new approach to the lesson. 
- $\quad$ The Educational Marketing training program developed my skills to promote the school I come from, implicitly to promote my own image, in conditions of increasing competition on the educational market, I learned to create advertising materials.

The teachers' perception about the frequency of participating in training courses is that this experience should be annual (73\%) and less than 5\% of the respondents said that it should be once every 5 years, as the current legislation in Romanian education provides, which indicates a very high level of responsibility, desire to update information, techniques, tools and working strategies, involvement, professional development among teachers in Romanian pre-university education.

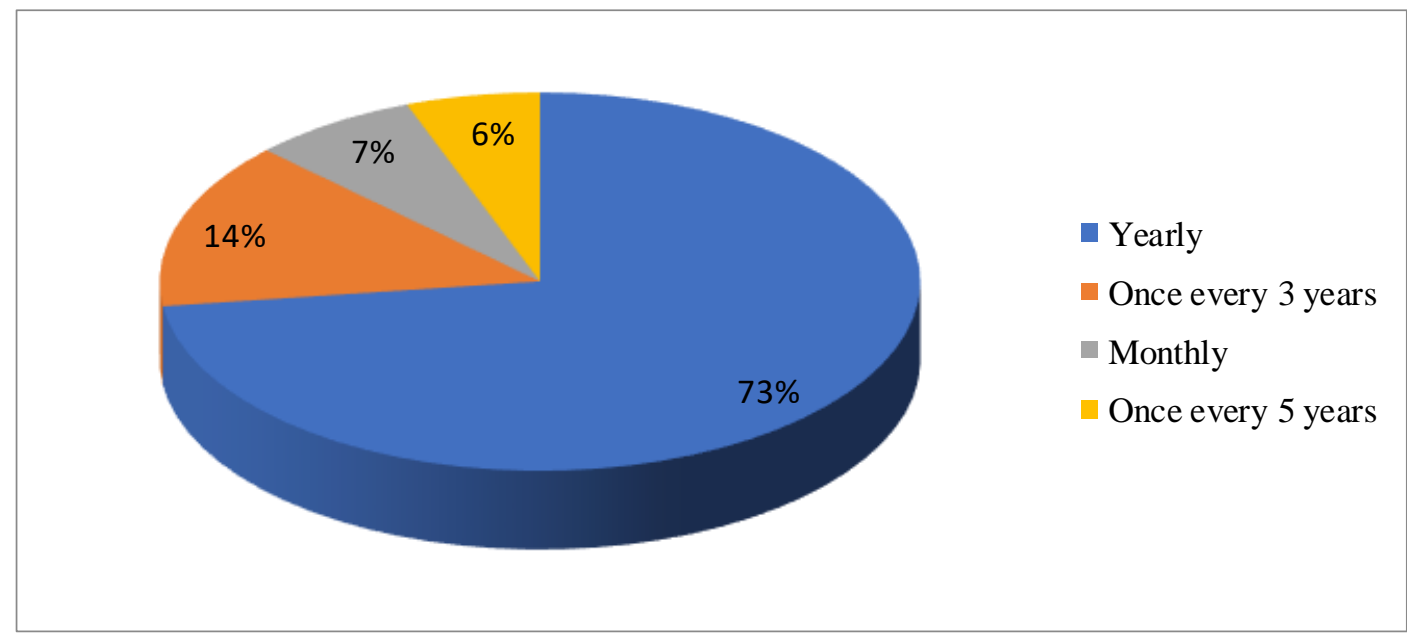

Figure no. 2 Teachers' perception about the frequency of participating in training courses

Respondents also consider courses, workshops and professional coaching activities to be the most effective ways of organising training programmes because they involve the exchange of best practices, the sharing of personal experiences with advantages and disadvantages, the active participation of learners while reducing the trainer's involvement, and focus on practical aspects and less on theoretical aspects, which teachers rarely encounter in their educational practice.

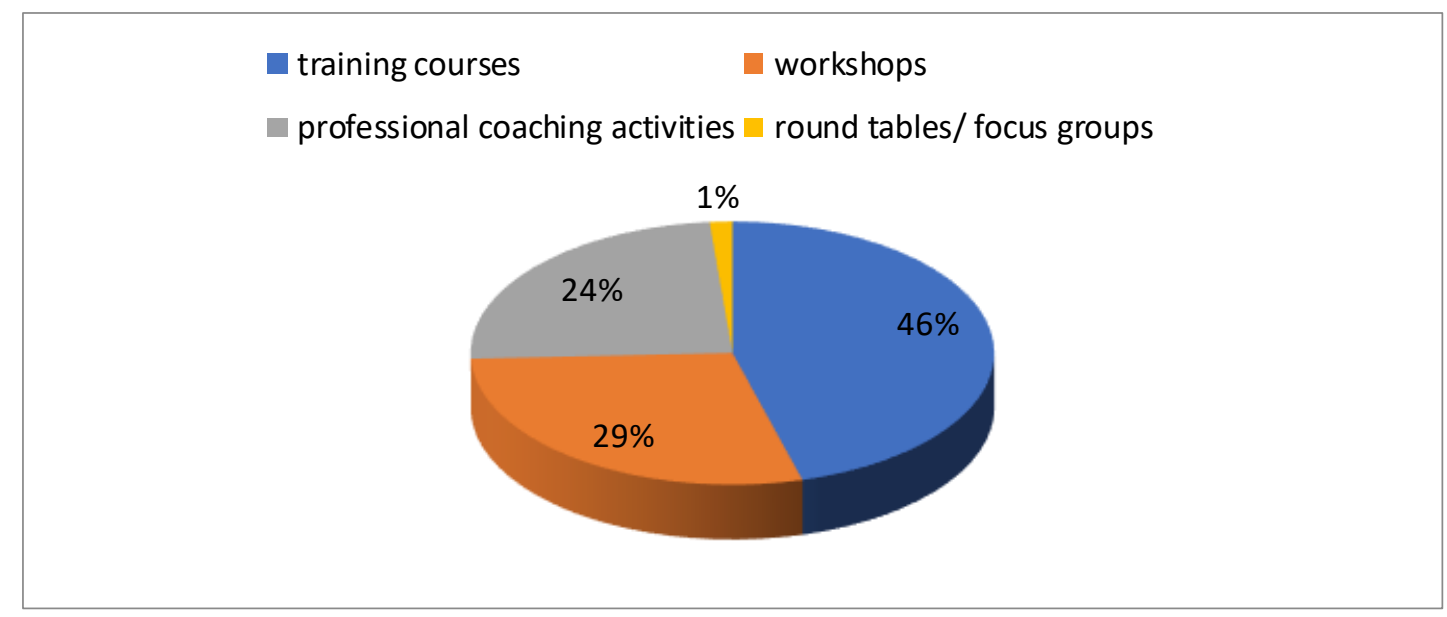

Figure no. 3 The most effective ways of organising training programmes as perceived by respondents 
According to the respondents, the most important consequences of the training activities were the following: innovation/optimisation of the educational approach, optimisation of the relationship/communication with students and development of research skills, while personal and school promotion were mentioned as less important. In order to get closer to identifying the success factors in continuing training programmes, respondents rated most highly the following aspects of their last training course, as illustrated in the figure below: the subject matter covered and the strategies used, then the experiences of colleagues, and least highly the management of time and the expertise and professional competence of the trainers.

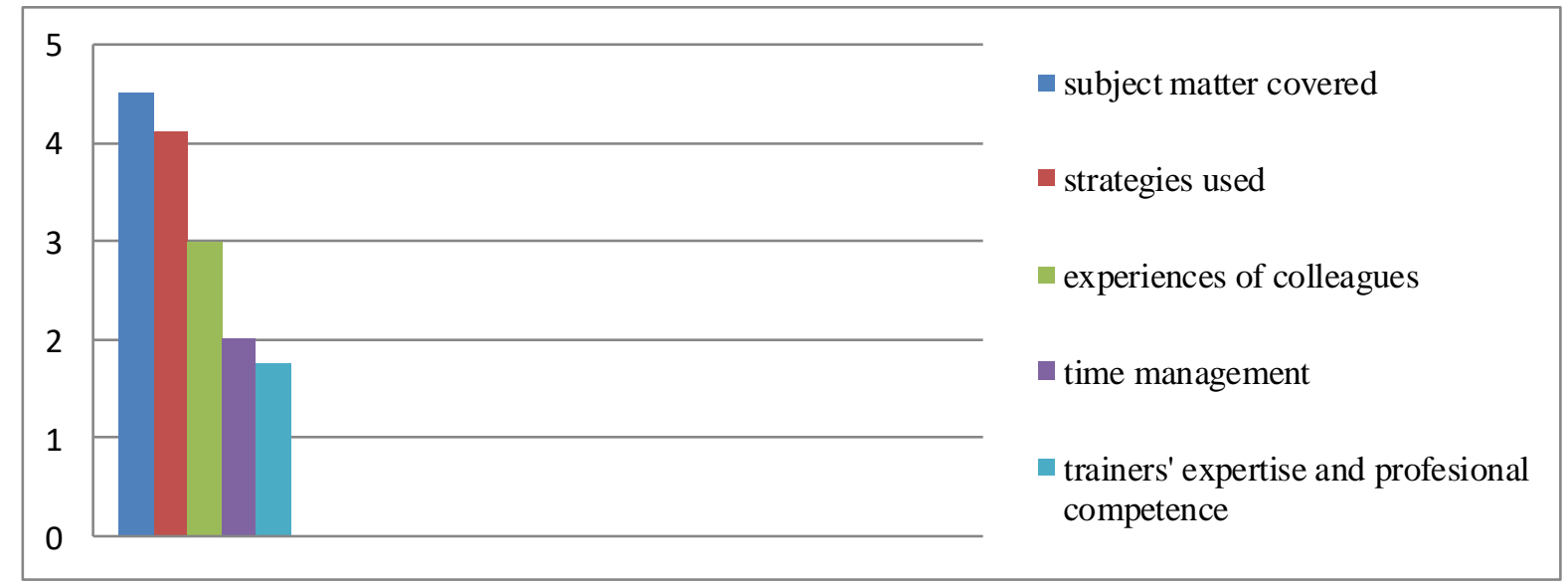

Figure no. 4 Respondents' perception of the success factors of continuing training programmes

Directly related to the competences of the training team, in terms of the success of a training programme, the respondents particularly appreciated the communication, evaluation competences, followed by the methodological and organisational competences, which indicates that these areas are of priority in the success of a course. Verbal, non-verbal and paraverbal communication skills, even in the online environment, remain the most important because they are reflected in participants' needs to understand and transfer what they learn in these continuing training programmes into their educational practice. Less importance is given to planning skills.

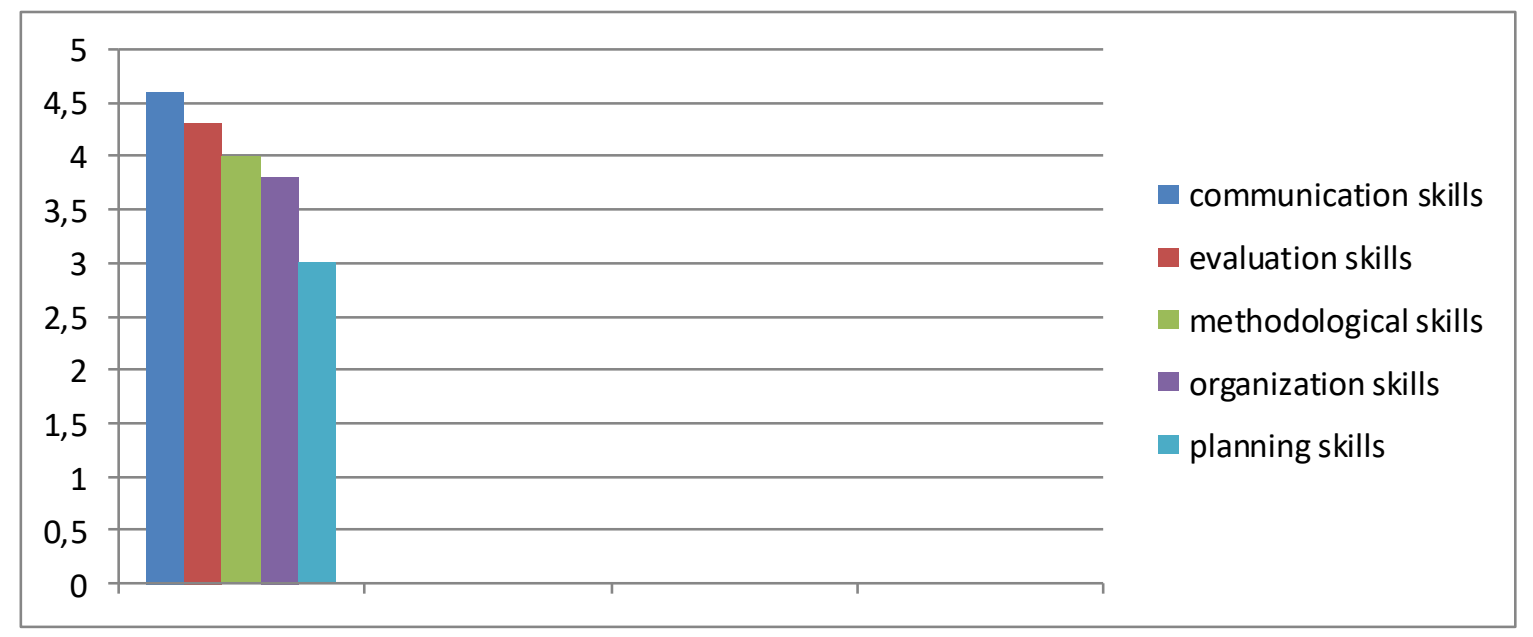


Figure no. 5 Respondents' perceptions of the skills of the training team.

As for the qualities most appreciated by respondents in the training team, they were: punctuality, originality and empathy, followed closely by adaptability and fairness. The ratings are justified by the fact that all of them should fit into the portrait of a competent trainer.

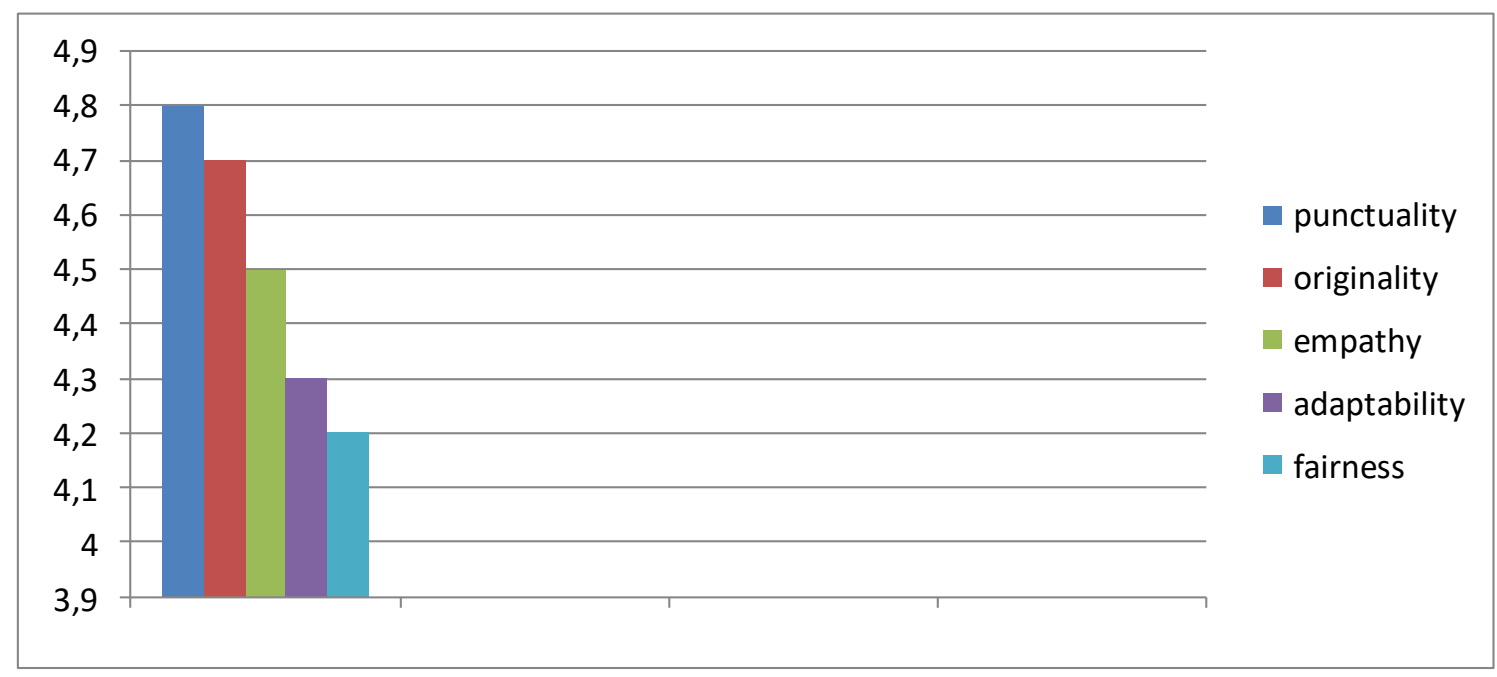

Figure no. 6 Respondents' perceptions of the qualities of the training team

The majority of respondents (46\%) noted that the trainer's qualifications were key to the success of the training programme they attended, followed by the subject matter, teaching materials used and methods, which in our opinion means that in the online environment success is ensured by the selection of methods and materials appropriate to the subject matter, relevant to educational practice and with significant content for the development of professional and transversal skills, given that the participants of the training courses have diverse specialties.

trainer's qualifications $\square$ subject matter $\square$ methods used $\square$ teaching materials used

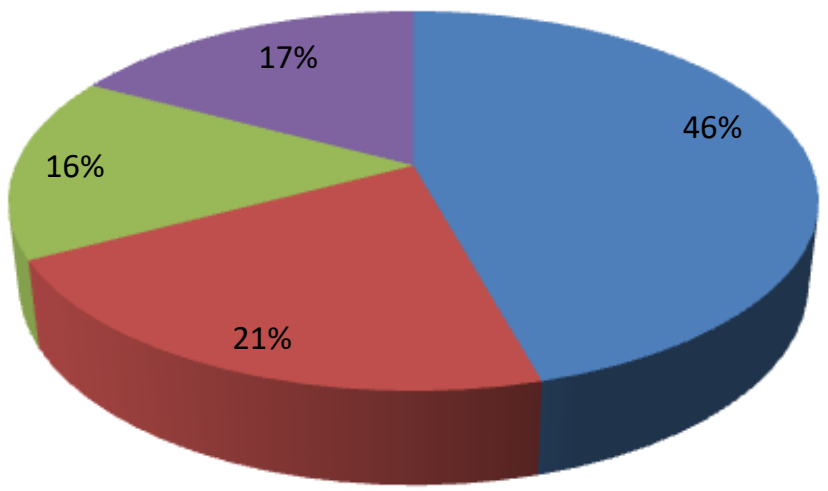

Figure no. 7 Respondents' perception of the success factors of an online training programme 
Because many of the skills and qualities of the training team, as well as the subject matter and teaching strategies used in the training courses, were among the common priorities, preferences and experiences of the teachers participating in the training courses where the questionnaires were administered, $73 \%$ of the respondents expressed a desire to participate in a similar training experience to a very great extent, $21 \%$ to a great extent, $4 \%$ to a moderate extent and only $2 \%$ to a small extent.

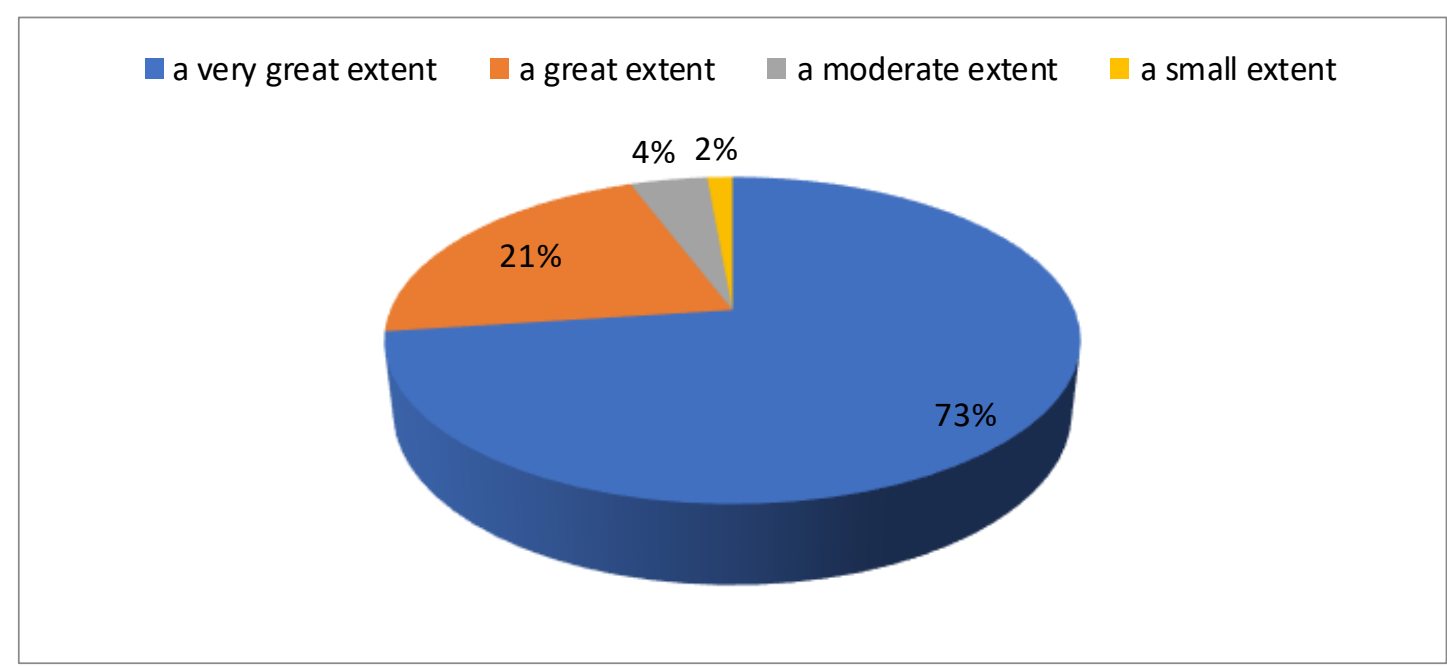

Figure no. 8 The extent to which respondents would still like to participate in a similar training experience

Following the analysis of these responses, we can conclude that the teaching staff in Romanian pre-university education wants to develop professional skills in a relatively short time, they particularly appreciate, at the level of continuous training programs, the video materials made available and the training of trainers. Teachers also want to be encouraged by the trainers during the course, showing that the advent of online schooling has somewhat shaken their confidence in their own strengths. At the same time, they appreciate the interaction with other colleagues during continuous training, the fact that they have gained some experience and have been able to reflect on ways of self-improvement, sharing experiences and personal practices.

\section{CONCLUSION}

This research explored the motivation and perceptions of teachers in Romanian preuniversity education in the midst of the pandemic and at the time online teaching became the norm, in terms of identifying the key to successful continuous training programmes.

Interpreting the results of the questionnaire applied to a number of 70 Romanian preuniversity teachers working in both rural and urban areas, we find that they are motivated mainly by the subject matter of the courses and the training of the trainers, by the communication and organisational teaching strategies, but also by originality, adaptability, and the way the continuous training programmes are organised, preferring those focusing on workshops and professional coaching activities.

In order to acquire the necessary skills for teaching in the online environment, teachers attach great importance to continuous training courses, sharing of personal educational experiences, communication skills and value the trainer for their psycho- 
pedagogical skills (communication, organization, selection of teaching strategies). The major disadvantage of the training programmes is the unfamiliarity with the platforms on which they are organised, which is why at the end respondents indicated that they would emphasise the in-depth exploration of the platform at the beginning of the course if they were trainers. Other limitations of our research would be related to the relatively small number of respondents, which does not allow generalization of the results, and the fact that the reporting was mainly done at the level of the last training course they attended and not at the level of all continuing training activities carried out during the pandemic.

In conclusion, we would like to point out that the hypothesis developed at the beginning of this research has been validated because after analysing and interpreting the results, we obtained the following information:

- $\quad$ Teachers need continuous training more frequently than is required by law, as well as support for the participation fee from the institution's budget, as shown by the answers to item 3.

- Almost half the teachers interviewed consider that they prefer training courses, followed by workshops and professional coaching, as shown by the answers to item 4 .

- The key to success was identified as trainer training, as indicated by respondents' answers to item 9. Therefore, in the questionnaire, teachers indicated that they would repeat the training experience with the trainer who gained their trust.

Teachers in pre-university education have a much greater need for professional development in the context of the pandemic, where the educational environment has been represented in particular by online schooling, IT skills being absolutely necessary for performance. With this, teachers will build on their communication and organisational skills and improve in their area of expertise, in order to be valued in turn as trainers for their own students or even colleagues.

\section{BIBLIOGRAPHY}

[1]Călin R., Pistritu, M., (2015). Formarea profesorilor în România şi Germania.Un studiu comparativ, Retrieved from: https://www.academia.edu/36002154/17_Calin_Razvan_Pistritu_Maria_Formarea_profesorilor_in_Ro mania_si_Germania_Un_studiu_comparativ_doc

[2]Comunicare a comisiei către parlamentul european, consiliu, comitetul economic și social european și comitetul regiunilor, (2017). Dezvoltarea școlilor și calitatea excelentă a predării pentru un început bun în viață, Retrieved from:

https://eur-lex.europa.eu/legal-content/ro/TXT/?uri=CELEX:52017DC0248

[3]European Commission/ EACEA/Eurydice (2018). Educația digitală a școlilor din Europa, Retrieved from: $\quad$ http://publications.europa.eu/resource/cellar/d7834ad0-ddac-11e9-9c4e01aa75ed71a1.0011.01/DOC_1

[4]Forest Divonne, M., (2019). Reinventează-ți viața profesională - Ghid practic pentru generația $Y$, București: Editura Trei,

[5] Formarea profesională a cadrelor didactice - repere pentru managementul carierei (2011). Retrieved from:

https://www.researchgate.net/publication/301823079_Formarea_profesionala_a_cadrelor_didactice__repere_pentru_managementul_carierei

[6]Iucu, R. (2004). Formarea cadrelor didactice - Sisteme, politici, strategii, Humanitas Educaţional, București

[7]Legea Educației Naționale nr. 1/2011, Art. 245. Retrieved from:

[8] https://legeaz.net/legea-educatiei-nationale-1-2011/art-245 
[9]Politici educaţionale în domeniul formării iniţiale şi continue a cadrelor didactice din sistemul de învătământ românesc,(2014). Retrieved from: https://concursurilecomper.ro/rip/2014/februarie2014/17-PanaitAlina Politici educationale.pdf

[10] Reghintovschi, S. (2021). Invățăm împărtășind - Ghid de experiențe scrise de și pentru specialișii $L \& D$, Editura Trei, București;

[11] Șerbănescu, L. Bocoș, M., D., Joja, I.(2020). Managementul programelor de formare continuă a cadrelor didactice, Iași: Editura Polirom

[12] Strategia de dezvoltare a sistemului de formare iniţială şi continuă a personalului didactic şi a managerilor din invăţământul preuniversitar-2001-2004, Retrieved from : https://gov.ro/fisiere/programe_fisiere/stratform.pdf 